\title{
Develompment of Water Sport Tourism Based on Sustainable Tourism in Pramuka Island, Thousand Islands DKI Jakarta
}

\author{
Rahmat Darmawan \\ Fakultas Ilmu Sosial \\ Universitas Negeri Jakarta \\ Jakarta, Indonesia \\ rahmat-darmawan@unj.ac.id
}

\author{
Jenal Abidin \\ Fakultas Ilmu Sosial \\ Universitas Negeri Jakarta \\ Jakarta, Indonesia \\ $\underline{\text { Jenal@wiyatatour.co.id }}$
}

\author{
H.Widyaningsih \\ Fakultas Ilmu Sosial \\ Universitas Negeri Jakarta \\ Jakarta, Indonesia \\ heniwidyaningsih@unj.ac.id
}

\begin{abstract}
This study aims to identify the potential of water sports tourism.This research uses qualitative research methods with reference to the concept of sports tourism, water based tourism and sustainable tourism. The population in this study was in the form of a social situation, namely Pramuka Island (land and water areas) with participants in it, Thousand Islands National Marine Park (TNLKPs), local tourism industry and Pramuka Island community. Research instruments in this study are observation, interviews and literature studies. Data analysis using the Miles and Huberman model with data triangulation. The results of this study indicate that Pramuka Island has the potential to be developed into a sports tourism destination in particular is skin diving, snorkeling, fishing. The strategy for developing sports tourism in Pramuka Island is increasing community participation in tourism activities, especially sport tourism based on water tourism, zoning area for marine sports tourism activities so as not to be confused with marine conservation areas and improving supporting facilities and infrastructure for marine sports tourism activities.
\end{abstract}

Keywords - sport tourism, water based tourism, sustainable tourism

\section{INTRODUCTION}

Indonesia archipelago is the largest in the world with a coastline length of more than $81,000 \mathrm{~km}$ and more than 17,508 islands and a sea area of about 3.1 million $\mathrm{km} 2$ so that Indonesia's coastal and marine areas are known as the countries with the largest marine biodiversity in the world by having coastal ecosystems such as mangroves, coral reefs and sea grass beds (Dahuri et al. 1996, p: 4). The natural beauty of Indonesia's marine life is quite remarkable, it can be seen from the marine park which is decorated by around 350 species of marine life consisting of coral reefs, shells, snails, turtles, fish, and thorny-skinned animals which is a huge potential for the development of the marine tourism industry. The strength of Indonesia's maritime tourism potential tempts many local and foreign tourists to take a vacation to enjoy its beauty (Cahyana et al. 2011, p: 1).

That's many islands in Indonesia, it turns out that not all of them have been developed into tourist destinations. One of the islands in Indonesia that has begun to be developed into a tourist destination is the Thousand Islands which is administratively located in DKI Jakarta Province. The Thousand Islands is one of the tourist destinations which is currently one of the alternatives for the people of Jakarta and surrounding areas to fill holiday time through tourist activities and also because the distance is not so far from Jakarta

Pramuka Island is one of the islands in the Thousand Islands cluster. This island is the capital of the Thousand Islands Regency. The development of tourism in Pramuka Island is currently quite significant, it can be seen from the number of tourist visits that continue to increase each year. According to the DKI Jakarta Tourism Office records the number of tourist arrivals at the end of 2017 amounted to more than two million people. This increase occurred because in addition to the accessibility element, it turned out that the tourist attraction of Scout Island also contributed to the increase in the number. One of its attractions is the Pramuka Island waters area which offers a variety of activities for tourists. The most popular tourist activities are fishing, snorkeling and diving. This activity is a form of water sports tourism which is the main activity and almost all tourists follow it.

Water sports activities are tourist activities that are often followed by tourists. The possible water sports 
activities are fishing, snorkeling, and diving because of the natural potential of the underwater which is very beautiful, such as coral reefs and the presence of other marine biota. However, as tourism develops on Pramuka Island, it turns out that there is a decrease in the quality of the environment, especially the underwater world. Currently the condition of coral reefs in the Thousand Islands has decreased (Terangi: 2013). The decline in the quality of coral reefs will threaten the development of tourism in the future, therefore it is necessary to develop water sports tourism activities that are able to create environmental sustainability so that the realization of sustainable tourism.

Tourism development is carried out to maximize profits and minimize problems (Mill, in between, 2011: 14) Tourism development basically takes into account several concepts such as: (1) Sustainable Tourism Development, (2) Integrated Regional Development and Tourism Product Development; (3) Tourism Economic Development; and (4) Environmental Development.

Sports Tourism is defined as a specific travel outside of the usual environment for either passive or active involvement in competitive sport where sport is the prime motivational reason for travel and the touristic or leisure element may act to reinforce the overall experience. Another definition worth noting explains sport tourism as a combination of sports activities and travel. From a sport marketing and sport management perspective, it consists of two broad categories of products: a) sports participation travel (travel for the purpose of participating in a sports, recreation, leisure or fitness activity); and b) sports spectatorial travel (travel for the purpose of spectating sports, recreation, leisure or fitness activities or events). (Pitts 1999 : 31)

Water-based tourism relates to any touristic activity (see definition below) undertaken in or in relation to water resources, such as lakes, dams, canals, creeks, streams, rivers, canals, waterways, marine coastal zones, seas, oceans, and ice-associated areas. (G. Jennings : 2010)

Sustainable tourism development (sustainable tourism development) tourism development that emphasizes the principle of sustainable development. WTO (1999), emphasizes that there are three important things in sustainable tourism development, namely:

- Quality. Sustainable tourism provides a quality experience for visitor, while improving the quality of the host community and protecting the quality of environment.

- Continuity. Sustainable tourism ensures the continuity of the natural resources upon which it based and the continuity of the cultural of the host community with satisfying experience for visitors.
- Balance. Sustainable tourism balances the need of the tourism industry, supporters of environment, and the local community.

Orams, (1999, hal:3) marine tourism includes those recreational activities that involve travel away from one's place of residence and which have as their host or focus the marine environment (where the marine environment is defined as those waters which are saline and tide-affected

\section{METHODS}

The study was conducted using qualitative methods and in this study an analysis will be made related to the condition of the Thousand Islands tourism, namely the geographical potential, supporting facilities and industries related to tourism, stakeholders related to tourism and others.

The population in this study is the Scouts, Thousand Islands, DKI Jakarta. Participants in this study consisted of several parties namely; The government, in this case is the DKI Jakarta Thousand Islands Tourism Office and the Thousand Islands National Park Office (TNKPs), the P. Pramuka community and tourism business actors and related industries such as owners of accommodation, transportation, consumption facilities, local tour operators and groups guide.

Data collection techniques are through interviews, observation and study of literature. During the data collection process, researchers conducted data analysis. The data analysis method (Huberman in Denzin et al, 2009 , p. 592) consists of three interrelated processes, namely
a. Data reduction,
b. Presentation of data,
c. Data verification.

Data analysis was carried out during the research activities, starting from the research planning stage, during the temporary data collection stage, to the final data collection stage.Data collected with a variety of techniques, before interpretation and to reduce interpretation errors, the researcher will test the validity of the data. Before data analysis is performed, certainty of data validity is required. Data validity tests are carried out to avoid the errors of data collected. The procedure used in testing data validity in general in qualitative research is triangulating different data sources by examining the evidence that comes from these sources and using them to build a coherent justification of themes. Themes that are built based on a number of data sources or perspectives from participants, this technique is often also referred to as data triangulation techniques (Creswell, 2012, p: 286). 


\section{RESULTS AND DISCUSSION}

One type of potential sports to be developed into sports tourism on Pramuka Island is marine sports (diving, kayaking, snorkeling, fishing)

A. SWOT Analysis (After identifying and analyzing internal and external factors, then the SWOT matrix was arranged as follows)

TABLE I. SWOT

\begin{tabular}{|c|c|c|}
\hline EFE & $\begin{array}{l}\text { (Strength) } \\
\text { 1. Easy and inexpensive accessibility to } \\
\text { reach Pramuka Island } \\
\text { 2. Has complete infrastructure facilities } \\
\text { supporting tourism } \\
\text { 3. The potential of nature and culture of } \\
\text { the people on Pramuka Island } \\
\text { 4. The existence of tourism institutions } \\
\text { The role of community participation in } \\
\text { tourism management }\end{array}$ & $\begin{array}{l}\text { Weakness } \\
\text { 1. Transportation facilities that have not } \\
\text { met the feasibility standard for tourism } \\
\text { 2. Lack of arrangement of facilities for } \\
\text { tourism } \\
\text { 3. Lack of public understanding to } \\
\text { manage natural and cultural potential } \\
\text { 4. Human resources are still low for } \\
\text { tourism development } \\
\text { Less optimal role of community } \\
\text { participation in tourism management }\end{array}$ \\
\hline $\begin{array}{l}\text { Opportunity } \\
\text { 1. The number of tourist arrivals has a } \\
\text { tendency to increase } \\
\text { 2. The trend of the marine tourism was } \\
\text { increased } \\
\text { 3. The development of the internet and } \\
\text { digital tourism } \\
\text { 4. The community participation in tourism } \\
\text { development was increasing }\end{array}$ & \begin{tabular}{|l} 
Strategi S-O \\
1. Improving the quality of tourism \\
infrastructure \\
2. The infrastructure facilities for natural \\
tourist attraction based on marine \\
tourism \\
3. $\begin{array}{l}\text { Increase online and offline marketing } \\
\text { of scout island destinations as a } \\
\text { maritime sports tourist destination }\end{array}$ \\
\end{tabular} & \begin{tabular}{|l}
\multicolumn{1}{c}{ Strategi W-O } \\
1. \\
Improve the quality of Pramuka Island \\
tourism services
\end{tabular} \\
\hline $\begin{array}{l}\text { Threat factor } \\
\text { 1. } \begin{array}{l}\text { Competitiveness of tourist destinations } \\
\text { with other islands }\end{array} \\
\text { 2. } \begin{array}{l}\text { Community awareness in maintaining } \\
\text { environmental sustainability }\end{array} \\
\text { 3. } \begin{array}{l}\text { Environmental damage to the } \\
\text { underwater area }\end{array} \\
\text { 4. Waste Issues } \\
\text { 5. Tourist Zoning Arrangement }\end{array}$ & \begin{tabular}{|l}
\multicolumn{3}{|c}{ S-T Strategy } \\
1. Improve the quality of Pramuka Island \\
as a tourist destinations \\
2. Improve the quality of tourism human \\
resources \\
3. Water sport tourism zoning \\
arrangements
\end{tabular} & \begin{tabular}{|l} 
W-T Strategy \\
1. $\begin{array}{l}\text { Improved destination quality and } \\
\text { image }\end{array}$ \\
2. $\begin{array}{l}\text { Increasing community participation in } \\
\text { sustainable tourism management }\end{array}$
\end{tabular} \\
\hline
\end{tabular}

\section{B. Internal Environmental Strategic Factor Analysis (IFAS Matrix)}

Based on the potential of marine sports tourism attraction that is owned by Pramuka Island in the form of natural resources related to marine and underwater tourism potential. In accordance with observations in the field there is an internal analysis related to tourism activities on Pramuka Island, namely the strength and weakness factors:

\section{Strength factor}

1. Easy and inexpensive accessibility to reach Pramuka Island

2. Has complete infrastructure facilities supporting tourism

3. The potential of nature and culture of the people on Pramuka Island

4. The existence of tourism institutions

5. The role of community participation in tourism management

\section{Weakness factor}

1. Transportation facilities that have not met the feasibility standard for tourism

2. Lack of arrangement of facilities for tourism

3. Lack of public understanding to manage natural and cultural potential

4. Human resources are still low for tourism development

5. Less optimal role of community participation in tourism management

The analysis of internal factors is carried out by determining the weights and ratings presented in the Internal Factor Evaluation matrix. The determination of the rating is carried out by stakeholders associated with tourism actors on Pramuka Island

\section{The External Environmental Strategic Factor Analysis (EFAS Matrix)}

Based on the analysis of opportunities and threats in tourism development on Pramuka Island, there is an 
external analysis related to tourism activities on Pramuka Island, namely:

\section{Opportunity factors}

1. The number of tourist arrivals has a tendency to increase

2. The trend of the marine tourism was increased

3. The development of the internet and digital tourism

4. The community participation in tourism development was increasing

\section{Threat factor}

1. Competitiveness of tourist destinations with other islands

2. Community awareness in maintaining environmental sustainability

3. Environmental damage to the underwater area

4. Waste Issues

5. Tourist Zoning Arrangement

Based on the SWOT analysis matrix, the development of sports tourism on Pramuka Island can be done as follows:

1. Improving the quality of tourism infrastructure that is environmentally sound, involving community participation. Especially for the development of marine sports tourism, of course this is related to infrastructure, Human Resources and the readiness of Pramuka Island as a tourist destination for sports both for recreational purposes and sports events that invite public participation.

2. Determine and regulate zoning for marine sports tourism activities that intersect with the Thousand Islands Marine National Park conservation area. The potential of underwater flora and fauna has become a potential attraction for marine sports tourism.

3. Provision of infrastructure facilities for natural tourism attraction based on marine sports tourism, because it is also possible as one of the destination marketing strategies can be done through sports event strategies on Pramuka Island.

\section{CONCLUSION}

Based on the results of the discussion it can be summarized that The potential possessed by Pramuka
Island can be developed into a sports tourism destination (Sport Toursm) especially marine sports tourism which is diving, snorkeling, fishing.

The strategies that can be taken in developing Pramuka Island as a sport tourism destination are as follows:

1. Improving the quality of tourist infrastructure with environmental insight, by involving public participation. Especially for the development of marine sports tourism, of course this is related to infrastructure, Human Resources and the readiness of Pramuka Island as a tourist destination for sports both for recreational purposes and sports events that invite public participation

2. Determine and regulate zoning for marine sports tourism activities that intersect with the Thousand Islands Marine National Park conservation area. The potential of underwater flora and fauna has become a potential attraction for marine sports tourism.

3. The pattern of assistance in water sports tourism especially open water sports by tour guides should refer to aspects of safety and environmental preservation so that the safety and comfort of tourists is the main thing

\section{REFERENCES}

(1) Cahyana,U., Supriyadi, Hamidah, Khaerudin, Partono, Tri \& Rahmat 2011 Pengembangan Model Marine Education Bank untuk meningkatkan Industri Wisata Bahari Menuju Ketahanan Ekonomi dan Penguatan Karakter Bangsa, Lembaga Penelitian UNJ, Jakarta

(2) Creswell, W, John. 2012. Research Design : Pendekatan Kualitatif, Kuantitatif dan Mixed. Pustaka Pelajar : Jogjakarta

(3) Dahuri, R., J. Rais, S.P. Ginting \& M.J. Sitepu, 1996 Pengelolaan Sumber Daya Wilayah Pesisir dan Laut Secara Terpadu. Pramadya Paramita : Jakarta

(4) Data Statistik Taman Nasional Kepulauan Seribu. 2009 Taman Nasional Kepulauan Seribu. Departemen Kehutanan.

(5) Denzin, K Norman, dan Yvonna S. Lincoln (Eds) 2009 Handbook of Qualitative Research, Terjemahan, Yogyakarta : Pustaka Pelajar,

(6) Departemen Kehutanan Republik Indonesia. 1990. Undang Undang Republik Indonesia Nomor 9 Tahun 1990 Tentang Kepariwisataan. Departemen Kehutanan Republik Indonesia : Jakarta.

(7) Gunn, AC. 1988. Tourism Planning : Second Edition. New York : Taylor \& Francis

(8) Jennings, Gyle. 2017. Water based tourism, sport, leisure and recreation experience UK : Elsavier 
(9) Luck, M, 2003. Education on marine mammal tours as agent for conservation-but do tourists want to be educated?, Ocean \& Coastal Management 46, 943-956, Elsevier

(10) Moleong, Lexy J, 2011. Metodologi Penelitian Kualitatif. Bandung : Rosda Karya.

(11) Mulyadi, A.J. 2009.KepariwisataandanPerjalanan.Jakarta :Rajawali Press.

(12) Orams MB. 1999, Marine Tourism: Development, Impacts And Management. London, New York: Routledge;.

(13)Pitts, B. 1999. Sports tourism and nichie markets: Identification and analysis of growing lebian and gay sports tourism industry.Journal of vacatioan Marketing

(14) Stephen D. Ross, Developing Sports Tourism a Guide for Destination Marketers and Sports Events Planners National Laboratory for Tourism and eCommerce July 2001

(15) Terangi, 2007. Terumbu Karang Jakarta : Pengamatan jangka Panjang terumbu Karang kepulauan Seribu (2003-2007) Yayasan Terangi Indonesia

(16) Yoeti, Oka A. 2008. Ekonomi Pariwisata (Introduksi, Informasi dan Implementasi). PT Kompas Media Nusantara. Jakarta. 